\title{
TEKNOLOGI DAN MASA DEPAN OTONOMI MANUSIA: SEBUAH KAJIAN FILSAFAT MANUSIA
}

\author{
Shely Cathrin \\ Program Studi Kebijakan Pendidikan, Universitas Negeri Yogyakarta \\ shelycathrin@uny.ac.id
}

\begin{abstract}
Abstrak
Penulisan artikel ini dilatarbelakangi oleh fenomena relasi manusia dengan teknologi akibat pesatnya perkembangan teknologi, komunikasi, dan informasi pada abad ke-21. Tujuan penulisan artikel ini adalah untuk melakukan refleksi atas teknologi dalam kajian filsafat manusia untuk memperdalam pemahaman tentang diri manusia. Artikel ini merupakan kajian pustaka dengan objek material berupa fenomena penggunaan gadget yang dianalisis dari objek formal filsafat manusia. Hasil studi menunjukkan bahwa teknologi pada dasarnya bersifat material atau berdimensi material. Roh manusia-lah yang menentukan arah dari teknologi itu. Betapa pun gadget membawa kebaikan pada manusia, ia adalah perangkat yang membahayakan. Ia mempunyai logikanya sendiri; arah tujuannya ditentukan berdasarkan rutenya sendiri; dan ia meleburkan manusia pada sebuah sistem yang otonom. Kata kunci untuk tetap menjaga otonomi manusia atas teknologi adalah pada kesadaran manusia. Pertama, manusia harus sadar bahwa teknologi perlu diperlakukan layaknya subjek; dan kedua, manusia harus sadar bahwa teknologi ada untuk manusia, sebagai sarana atau media untuk mematerial-kan ide-ide dan gagasan manusia. Semuanya mengarah pada satu tujuan: demi membuat dunia manusia sesuai dengan kebutuhan manusia. Dengan berpegang pada dua hal tersebut, maka otonomi manusia atas teknologi akan tetap ada. Manusia tidak boleh jatuh pada teknologi karena teknologi untuk manusia bukan sebaliknya.
\end{abstract}

Kata kunci: Teknologi, Gadget, Manusia, Otonomi, Kesadaran

\begin{abstract}
The writing of this article is motivated by the phenomenon of human relations with technology due to the rapid development of technology, communication and information in the 21st century. The purpose of writing this article is to reflect on technology in the study of human philosophy to deepen understanding of human beings. This article is a literature review with material objects in the form of the phenomenon of using gadgets analyzed from the formal object of human philosophy. The results of the study show that technology is basically material or material in dimension. It is the human spirit that determines the direction of the technology. No matter how good gadget brings goodness to humans, it is a dangerous device. It has his own logic; the direction of the destination is determined by its own route; and it fuses humanson an autonomous system. The key word for maintaining human autonomy over technology is on human consciousness. First, humans must be aware that technology needs to be treated
\end{abstract}


like a subject; and second, humans must be aware that technology exists for humans, as a means or media for materializing human ideas and thought. It all leads to one goal: to make the human world in accordance with human needs. By adhering to these two things, human autonomy of technology will remain. Humans must not fall on technology because technology is for humans, not the opposite.

Keywords: Technology, Gadgets, Humans, Autonomy, Awareness

\section{PENDAHULUAN}

\section{Dialektika Manusia dan Teknologi}

Manusia adalah makhluk yang memiliki banyak kekhasan. Salah satu kekhasan manusia yang menjadi pembeda utama manusia dengan makhluk yang lainnya adalah kemampuannya untuk mempertanyakan segala sesuatu. Manusia memiliki rasa ingin tahu yang sangat besar tentang segala hal. Rasa ingin tahu ini bahkan sudah terlihat ketika manusia masih anak-anak. Dalam kehidupan sehari-hari, sering ditemui pertanyaan-pertanyaan spontan, menggelikan, dan kadang rumit dari anak-anak tentang segala macam hal. Mengapa api itu panas; mengapa ada matahari; apa itu bumi; mengapa manusia mati; adalah contoh pertanyaan-pertanyaan yang kadang muncul dari anak-anak kecil yang masih polos. Manusia memang makhluk yang bertanya, demikian kata Sihotang dalam bukunya Filsafat Manusia (2009). Manusia adalah satu-satunya makhluk yang mampu bertanya. Satu hal yang luar biasa dari kemampuan manusia tersebut adalah, kemampuannya mempertanyakan segala hal. Ia mempertanyakan dunianya, keberadaannya, bahkan dirinya sendiri (Sihotang, 2009). Segala hal bisa menjadi bahan renungannya. Segala hal bisa direfleksikan oleh manusia. Tidak salah karenanya jika Socrates ribuan tahun silam mengarahkan perhatian filsafat pada persoalan manusia.

Di antara sekian banyak hal yang menjadi pertanyaan manusia, 'dunia' barangkali adalah satu hal yang menjadi gudang pertanyaan yang tiada habisnya. Oleh karena alasan ini pula, relasi antara manusia dan dunianya menjadi salah satu persoalan utama dalam kajian filsafat manusia. Setiap hari manusia berhadapan dengan dunianya melalui berbagai macam fenomena, baik fenomena alam maupun fenomena sosial. Pada proses ini terjadi 
hubungan yang unik antara manusia dengan dunia. Di satu sisi, manusia berada-dalam-dunia, dalam artian segala tindakannya sangat dipengaruhi oleh dunianya; namun di sisi yang lain manusia juga mengatasi dunia, dalam arti ia berusaha menjawab tantangan dunia dengan merekayasa 'dunia'. A. Snidjers menyebut relasi antara manusia dan dunia ini bersifat imanen dan transenden sekaligus (Snidjers, 2004). Imanen karena manusia selalu terkungkung dalam dunia; transenden karena manusia berusaha mengatasi kungkungan dunia dengan melakukan rekayasa terhadapnya.

Bertolak dari relasi antara manusia dengan dunia inilah, kemudian muncul budaya. Manusia adalah makhluk yang membudaya (Snidjers, 2004). Manusia mampu memproduksi dan mereproduksi kebudayaan dengan menjawab tantangan alam yang dihadapinya setiap hari. Manusia selalu berusaha membuat dunia menjadi rumahnya (Snidjers, 2004). Seiring dengan perkembangan zaman, manusia melakukan dekonstruksi, modifikasi, dan rekonstruksi terhadap dunia sehingga lahirlah capaian-capaian besar dalam sejarah manusia. Capaian-capaian tersebut tersebar pada segala aspek kebudayaan, yang didalamnya terdapat sebuah struktur yang universal atau sering disebut dengan istilah cultural universals dalam diskursus kebudayaan. Kontjaraningrat, dalam bukunya yang berjudul Kebudayaan, Mentalitas, dan Pembangunan, menyatakan bahwa cultural universal itu berjumlah tujuh, yang disebut dengan istilah unsur kebudayaan. Tujuh unsur tersebut adalah sistem kepercayaan; sistem pengetahuan; sistem teknologi dan peralatan; sistem mata pencaharian; sistem organisasi sosial; bahasa; dan kesenian (Koentjaraningrat, 2004). Di antara ketujuh unsur tersebut, salah satu unsur yang bagi penulis sangat menarik untuk dikaji adalah tentang sistem teknologi dan peralatan.

Manusia, dalam hubungannya dengan dunia, selalu berusaha mengubah dunia agar sesuai dengan kebutuhannya (Snidjers, 2004). Manusia menanam padi agar kebutuhan pangannya terpenuhi, tidak hanya untuk hari ini, tetapi juga untuk masa-masa yang akan datang. Manusia membangun rumah sebagai pelindung dari teriknya matahari dan dinginnya malam. 
Manusia senantiasa menjawab tantangan alam dan merekayasa alam demi menjamin keberlangsungan hidupnya di masa depan. Namun demikian, dalam menjawab tantangan alam, manusia menemui keterbatasan-keterbatasan, khususnya menyangkut hal fisik atau material. Ketika menanam pohon, manusia ingin menggali sedalam-dalamnya, tapi apa daya, tangannya tidak mampu melakukannya. Berawal dari keterbatasan fisik itulah, manusia kemudian menciptakan teknologi. Muncullah apa yang kemudian dinamakan dengan alat atau tools. Tools, mengacu pada alat-alat atau perkakas yang menyempurnakan kerja tangan manusia (Snidjers, 2004). Teknologi menjadikan hidup manusia menjadi lebih mudah. Keterbatasan-keterbatasan fisik mulai teratasi. Meskipun dunia tidak pernah sesuai dengan keinginan manusia, tetapi dengan teknologi keadaan dunia semakin mendekati proyeksi dari keinginan manusia.

\section{PEMBAHASAN}

\section{Gadget: Mengancam Otonomi Manusia?}

Memasuki awal abad ke-21, tidak dapat dipungkiri teknologi telah berkembang dengan pesat. Manusia, dengan potensi yang ada pada dirinya, menjawab tantangan alam dengan teknologi. Semakin berat tantangan alam, teknologi yang dihasilkan pun semakin canggih. Manusia, dengan daya kreatifnya, menjawab tantangan alam dengan berbagai inovasi di bidang teknologi yang cenderung semakin memuncak seiring dengan berjalannya waktu. Kini, teknologi telah merasuki hampir seluruh aspek dan seluruh area dalam kehidupan manusia; baik area privat maupun area publik. Manusia menjalin hubungan yang semakin intens dengan teknologi. Setiap saat ia 'bergaul' dengan teknologi. Manusia, bahkan, 'bergaul' dengan diri sendiri dan manusia yang lain melalui teknologi. Manusia mengenal dunia melalui teknologi dan ia berada-bersamateknologi.

Berbicara mengenai perkembangan teknologi, ada satu teknologi 
yang saat ini sedang menjadi 'primadona', yaitu perkembangan teknologi informasi, melalui satu perangkat yang kini populer adalah gadget. Menurut Camridge Dictionary, istilah 'gadget' memiliki makna: a small device or machine with a particular purpose (Cambridge Dictionary). Berdasarkan makna dari kamus tersebut, dapat diketahui bahwa istilah gadget sebenarnya memiliki cakupan yang luas karena semua alat atau mesin yang memiliki kegunaan khusus, bisa dikategorikan sebagai gadget. Sebagai contoh, pisau, panci, dan kompor adalah kitchen gadgetery atau peralatan dapur. Kini, pemahaman terhadap istilah gadget semakin menyempit, khususnya di kalangan masyarakat. Masyarakat atau media massa, umumnya mengasosiasikan istilah gadget sebagai perangkat elektronik kecil yang memiliki fungsi khusus. Ketika menyebut istilah gadget, yang terbersit di kepala adalah handphone, tablet, perangkat game portable, dan sejenisnya.

Sebagaimana dikemukakan oleh A. Snidjers (2004), teknologi sebenarnya berkaitan dengan aspek materialitas manusia, begitu pula dengan gadget. Gadget adalah benda material yang umumnya terdiri atas dua unsur. Pertama adalah unsur hardware atau perangkat kerasnyayang mengacu pada bahan yang digunakan untuk membuat gadget, dapat berupa plastik, polikarbonat, alumunium, bahkan emas. Kedua adalah unsur software atau perangkat lunak, yaitu sistem operasi (operation system) yang juga menjadi salah satu penentu berfungsinya perangkat tersebut. Sistem operasi sebuah perangkat-lah yang sebenarnya menjadi media manusia untuk 'berinteraksi' dengan gadget karena tanpa sistem operasi, sebuah gadget adalah sebuah artefak saja. Dengan adanya software, gadget seolah-olah memiliki 'roh'. Ia bisa dimainkan, ia menjadi teman manusia, ia bahkan bisa menjadi 'pasangan' manusia. Bulan Juli 2016 lalu, media massa dihebohkan dengan seorang pria di Las Vegas, Amerika Serikat yang memutuskan untuk menikahi iPhone-nya (Muhaimin, 2016). Peristiwa tersebut, bagi sebagian manusia adalah peristiwa yang aneh, namun dari peristiwa tersebut bisa dilihat bahwa manusia sudah sangat 
tergantung pada teknologi. Bagi pria tersebut, gadget mungkin dianggap jauh lebih humanis dibandingkan perempuan mana pun. Tetapi, apa benar demikian?

Saat ini teknologi gadget baik hardware maupun software-nya sudah berkembang dengan sangat cepat. Setiap saat, gadget terlahir; menawarkan desain material baru dan berbagai fitur baru melalui sistem operasi yang dibenamkan di dalamnya. Salah satu perkembangan yang terbaru adalah dalam bentuk wearable gadget atau gadget yang dapat dipakai (menempel) pada tubuh manusia. Wearable gadget yang ada pada saat ini adalah dalam bentuk jam tangan pintar (smartwatch) dan virtual reality glassess (kacamata realitas virtual). Ide penciptaan wearable gadget berupa smartwatch sebenarnya lahir dari tuntutan portabilitas teknologi. Ketika desktop PC (komputer yang diletakkan di meja) tidak lagi cukup portabel, manusia membuat laptop. Ketika laptop tidak cukup portabel, manusia membuat smartphone (pocket PC). Ketika manusia menggunakan smartphone, ternyata ia masih tergantung pada laptop, lalu dibuatlah tablet $P C$ yang semakin portabel dari laptop. Kini, ketika smartphone dianggap kurang portabel karena masih terpisah dari manusia (misalnya ditaruh di tas atau di saku) muncul kebutuhan untuk membuat gadget yang menyatu dengan tubuh manusia. Gadget ini menempel, bisa dipakai, dan mewujud dalam satu perangkat kecil bernama jam tangan pintar (smartwatch).

Di antara sekian banyak perangkat smartwatch yang dirilis oleh berbagai perusahaan teknologi, terdapat Apple Watch yang dirilis oleh perusahaan teknologi dari Cupertino AS, yaitu Apple Inc. Jam tangan ini menjadi populer di kalangan penikmat teknologi bukan hanya karena ia dibuat oleh perusahaan yang menjadi kiblat teknologi; tetapi juga karena ia menawarkan berbagai fitur yang disebut 'humanis' oleh Apple. Salah satu fitur unggulannya adalah kemampuan mendeteksi pergerakan pemakainya (motion sensor), termasuk kemampuan mendeteksi detak jantung. Kegunaan dari fitur ini adalah untuk mendeteksi kondisi kesehatan pemakainya. Data yang terintegrasi dengan iPhone tersebut kemudian 
digunakan untuk merekomendasikan aktivitas yang 'harus' dilakukan oleh pemakai smartphone besutan Apple ini. Lewat aplikasi "Health" di iPhone, pengguna akan membuat Medical ID, semacam database yang berisi informasi medis pemakai jam, misalnya berat badan, tinggi badan, riwayat penyakit, dan sebagainya. Data di Medical ID inilah yang kemudian menjadi dasar bagi aplikasi "Health" untuk memberikan rekomendasi kepada pemakai Apple Watch, kapan ia harus minum, kapan ia harus duduk, kapan ia terlalu lama berdiri, seberapa jauh ia harus berlari untuk membakar kalorinya, dan sejenisnya. Singkatnya, Apple Watch menjadi konsultan kesehatan yang mengerti kebutuhan penggunanya.

Berbagai fenomena yang tampak dalam relasi antara manusia dengan teknologi di atas, tampaknya memang tidak menjadi masalah. Namun demikian, jika direfleksikan lebih lanjut, ada persoalan serius terkait dengan otonomi manusia atas teknologi. Persoalan inilah yang menjadi penting untuk dibicarakan dalam kajian filsafat manusia. Kasus pernikahan seorang pria dengan iPhone tadi misalnya. Apakah relasi manusia dan teknologi semacam ini adalah satu kemajuan besar dalam sejarah umat manusia? atau justru kemerosotan manusia karena ketidakberdayaannya di depan teknologi mungil bernama gadget? Mengutip pendapat Snidjers, refleksi atas teknologi dalam kajian filsafat manusia dimaksudkan untuk memperdalam pemahaman tentang diri manusia. Alasannya sederhana, teknologi terlahir karena dan untuk manusia; bukan sebaliknya (Snidjers, 2004).

\section{Gadget: Adanya 'Karena' dan 'Untuk' Manusia}

Bakker (1984) dalam bukunya Filsafat Kebudayaan mengemukakan bahwa ilmu bisa berkembang menjadi teknologi karena adanya creative vision. Sederhananya, visi kreatif ini berkaitan dengan bayangan tentang masa depan yang berpadu dengan naluri untuk menciptakan (creating). Hasilnya adalah penciptaan produk-produk teknologi yang memang menjadi proyeksi keinginan masa depan yang 
lebih baik. Pendapat serupa juga dapat dijumpai dalam pemikiran A. Snidjers (2004). Menurutnya, faktor-faktor yang menggerakkan manusia menjadi 'manusia teknik' adalah: paradoks manusia; rasa ingin tahu; dan dorongan etis. Dari ketiga faktor tersebut, paradoks manusia adalah hal yang paling menarik untuk dibahas bagi penulis. Maksud dari paradoks manusia adalah bahwa manusia selalu dalam paradoks antara yang materi dan yang rohani. Teknologi pada dasarnya bersifat material. Dengan kata lain, ia berdimensi material. Roh manusia-lah yang menentukan arah dari teknologi itu, yang oleh Bakker (1984) disebut creative visions. Rohani manusia-lah yang menggerakkan arah dari perkembangan teknologi, bagaimana teknologi seharusnya bekerja, dan bagaimana seharusnya teknologi memberikan dampaknya kepada manusia. Ketika manusia menciptakan teknologi bernama gadget, creative visions semacam ini juga menjadi latar belakang penciptaannya. Persoalannya, menjadi lebih kompleks dari yang dibayangkan karena kenyataannya ada dampak yang tidak pernah diduga oleh manusia dari teknologi yang diciptakannya itu. Wearable gadget bernama Apple Watch kembali akan menjadi ilustrasi untuk membahas hal ini.

Apple Watch adalah perangkat mungil yang dibekali dengan fitur kesehatan yang bisa mendeteksi aktivitas tubuh pemiliknya. Gadget sejenis smartwatch ini sempat tenggelam dalam hiruk pikuk euforia teknologi informasi karena tertutup oleh selebrasi peluncuran perangkat pemutar musik portabel dan smartphone kala itu. Tahun 2013, smartwatch kembali meramaikan perkembangan teknologi setelah Samsung meluncurkan Samsung Gear, perangkat smartwatch pertamanya. Belakangan, smartwatch menjadi sangat populer setelah Apple ikut meramaikan pasar dengan meluncurkan Apple Watch. Apple bahkan saat ini mendominasi pasar penjualan smartwatch lewat penjualan Apple Watch-nya (Don Reisinger, 2016).

Data di atas penulis sampaikan bukan dalam rangka menunjukkan betapa populernya Apple sebagai perusahaan teknologi. Penulis, melalui 
data di atas ingin menunjukkan bahwa dengan larisnya produk Apple Watch, maka tentu sudah banyak orang yang berinteraksi dengan gadget tersebut. Dengan kata lain, tidak sedikit manusia yang sudah merasakan dampak dari interaksi mereka dengan teknologi yang baru tersebut. Apakah dampak tersebut positif atau negatif?

\section{Teknologi dan Otonomi Manusia}

A. Snidjers (2004) menyatakan bahwa manusia adalah makhluk paradoksal. Oleh karenanya, tidak mengherankan jika paradoks ini juga terdapat di dalam produk-produk hasil karya manusia. Termasuk juga teknologi informasi yang bernama gadget. Tidak bisa dipungkiri ada banyak dampak positif dari teknologi informasi. Efektivitas dan efisiensi menjadi keunggulan utama dari teknologi informasi ini. Namun demikian, manusia sekarang mulai tersadar bahwa teknologi informasi, khususnya gadget ternyata tidak selamanya membawa kebaikan. Seiring dengan perjalanan waktu muncul dampak-dampak negatif dari gadget tersebut. Penulis mencoba mengidentifikasi dampak buruk tersebut menjadi tiga. Pertama, manusia kehilangan kontrol atas dirinya. Manusia menjadi terlalu asyik bermain. Ia lupa waktu; ia lupa pekerjaan. Meminjam bahasa Baudrillard, gadget menyajikan gambaran-gambaran tentang hiperealitas lewat game, lewat aplikasi, lewat foto, Smule, Instagram, dan sebagainya. Manusia semakin tenggelam dalam dunia simulasi, bahkan kecanduan terhadap "realitas kedua" (second reality) sehingga ia lupa akan "realitas pertama" (first reality). Memang manusia dianggap sebagai homo ludens, makhluk yang bermain. Tetapi ilustrasi di atas tidak hanya menyangkut aspek kodrati manusia. Lebih dari itu, gadget membuat manusia kehilangan otonominya karena terlalu larut dalam permainan teknologi. Kedua, ketika gadget menjadi candu, salah satu dampaknya adalah berupa perilaku konsumtif terhadap gadget atau yang disebut dengan gadget freak. Ketika muncul gadget baru, buru-buru ingin membeli. Ketiga, karena gadget, manusia tak lagi bisa fokus pada pekerjaannya. Ia tak lagi 
bisa membedakan dengan jelas, yang mana pekerjaan, yang mana permainan. Pekerjaan dan permainan lebur menjadi satu. Work and Play sudah melebur jadi satu sebagaimana dikampanyekan oleh Microsoft, perusahaan software dari Amerika Serikat ketika mengenalkan sistem operasi Windows 8. Contoh lain juga dapat dilihat pada fenomena umum di masyarakat tentang penggunaan aplikasi instant messaging paling populer, yaitu Whatsapp. Lewat aplikasi ini, pekerjaan dan permainan menjadi satu. Atasan kerja, bawahan, rekan sepermainan, teman SD, teman SMP, teman main musik, relasi satu keluarga, semuanya tumpah ruah dalam satu aplikasi: Whatsapp. Interaksi yang terjadi dalam aplikasi ini pun terkadang menggelikan dan rumit. Satu saat manusia berkomunikasi dengan atasannya dengan bahasa formal di grup yang satu; satu saat yang lain ia berkomunikasi dengan teman sepermainannya dengan bahasa yang penuh canda dan humor. Pada saat yang lain, pesannya masuk ke grup yang salah. Poinnya adalah, lewat aplikasi ini manusia tak lagi bisa lepas dari gadget. Pekerjaan pun bahkan sudah melebur dalam aplikasi Whatsapp ini. Pekerjaan bisa menjadi permainan karena seseorang berkomunikasi dengan atasannya lewat aplikasi layaknya mainan. Sebaliknya, mengecek satu demi satu pesan Whatsapp yang tampaknya hanya seperti bermain gadget, ternyata bisa menjadi pekerjaan.

Melalu ilustrasi di atas, penulis ingin menunjukkan bahwa gadget merupakan ancaman besar bagi otonomi manusia. Manusia tak bisa lepas dari gadget. Ia bermain gadget, tetapi ia tidak bisa lepas darinya karena dalam bekerja pun ia menggunakan gadget. Waktu manusia habis untuk berinteraksi dengannya. Tidak jarang pekerjaan menjadi berantakan karena manusia terlalu asyik berinteraksi dengan gadget-nya. Pertanyaannya, lalu di mana otonomi manusia atas gadget? Di depan perangkat kecil saja ternyata manusia tampak tidak lagi berdaya.

Pertanyaan semacam ini bukanlah pertanyaan yang baru dalam dunia filsafat. Kegelisahan para filsuf akan pengaruh teknologi terhadap masa depan manusia pun sudah mengemuka begitu lama. Beberapa filsuf 
sudah 'membaca' bahwa pada akhirnya teknologi akan menggerus otonomi manusia. Semakin maju teknologi, semakin tidak jelas, mana yang sesungguhnya otonom. Manusia; atau teknologi? Manusia; atau gadget? Dalam sebuah antologi artikel tentang filsafat teknologi berjudul Philosophy of Technology, The Technological Condition (2003) terdapat satu bab dengan tajuk "Technology and Human Ends". Apakah teknologi mematikan manusia? Sedemikian parahkah bahaya teknologi di era kontemporer bagi masa depan manusia?

Salah satu filsuf yang mencoba menjelaskan apa yang sebenarnya terjadi di antara manusia dan teknologi adalah Jacques Ellul (1912-1994). Jacques Ellul adalah filsuf Perancis kontemporer yang menaruh perhatian pada persoalan teknologi dan otonomi manusia. Melihat konteks ketika Ellul hidup (1912-1994) dapat diketahui bahwa Ellul hidup di masa ketika teknologi sudah berkembang sedemikian pesat meskipun teknologi informasi belum berkembang secanggih saat ini. Namun demikian, mencermati artikelnya tentang konsep otonomi teknologi, dapat dilihat bahwa pemikiran Ellul masih relevan hingga sekarang.

Kembali pada pertanyaan awal dalam pembahasan ini. Manakah yang otonom di dunia kontemporer yang sudah penuh sesak dengan gadget saat ini? Manusia atau gadget? Menjawab pertanyaan ini, sikap Ellul sangat jelas bahwa otonomi ada pada teknologi. Ellul menyatakan sebagai berikut.

“...technology ultimately depends only on itself, it maps its own route, it is a prime and not a secondary factor, it must be regarded as an "organism" tending toward closure and self-determination: it is an end in it self" (Elul, 2003).

Manusia menciptakan teknologi, tapi kini teknologi sudah 'mengambil' alih otonomi manusia. Teknologi seolah-olah memiliki logika-nya sendiri. Ia ditentukan oleh dirinya sendiri. Deterministik, itulah ciri pemikiran Jacques Ellul.

Otonomi teknologi yang mengatasi otonomi manusia 
sebagaimana dikemukakan oleh Ellul tersebut dapat dilihat dengan jelas dalam contoh yang penulis sampaikan pada pembahasan awal tulisan ini. Apple Watch, wearable gadget yang diciptakan untuk "mengerti" manusia itu ternyata justru terkesan "sok" mengerti manusia. Pemakai gadget ini mungkin akan terbiasa dengan situasi-situasi seperti ini. Ketika sedang bersantai sambil duduk, tiba-tiba jam tangan bergetar, 'memaksa' pemakainya berdiri karena dianggap terlalu lama duduk; itu tidak baik untuk kesehatan. Di tengah-tengah pesta berdiri (standing party) tiba-tiba jam membuat bingung pemakainya gara-gara notifikasi yang 'menyuruh' pemakainya duduk; lagi-lagi karena itu tidak baik untuk kesehatan. Ketika badan sudah lelah sehabis berlari $3 \mathrm{Km}$, tiba-tiba jam memberikan notifikasi bahwa masih perlu berlari $2 \mathrm{Km}$ lagi untuk membakar kalori pemakainya; ini demi kesehatan pemakainya. Manusia pada akhirnya harus 'tunduk' pada sistem teknologi yang dibenamkan pada perangkat smartwacth itu. Pada kasus-kasus seperti ini, jam tangan yang tadinya diciptakan dengan semangat "teknologi yang mengerti manusia" berubah menjadi "teknologi yang mendominasi manusia". Ia merasa lebih tahu pemakainya harus minum berapa gelas; harus berlari puluhan $\mathrm{Km}$; harus duduk berapa jam; atau harus terus berdiri agar kalorinya terbakar. Semuanya berjalan karena logika yang dibenamkan dalam teknologi. Karena teknologi yang diciptakannya, manusia kehilangan otonomi, dan dalam beberapa hal, situasi ini menyedihkan.

\section{SIMPULAN}

\section{Dialektika Roh-Materi dalam Relasi Manusia-Teknologi}

Berpijak pada pemikiran Jacques Ellul di atas, dapat diketahui bahwa betapa pun gadget membawa kebaikan pada manusia, ia adalah perangkat yang membahayakan. Kini, ia mempunyai logikanya sendiri; arah tujuannya tentukan berdasarkan rutenya sendiri; dan ia meleburkan manusia pada sebuah sistem yang otonom. Lantas, bagaimana manusia semestinya menyikapi 
gadget? Jika memahami kecenderungan masyarakat dalam menyikapi karakter gadget yang seperti itu, ada dua kecenderungan sikap yang muncul. Pertama adalah gadgetphobia, yaitu sikap untuk menolak sama sekali segala bentuk kemajuan yang ditawarkan oleh teknologi bernama gadget. Kedua, adalah gadgetfreak, sebuah sikap yang merayakan 'kematian' otonomi manusia dan memilih untuk larut dalam hingar bingar dunia gadget yang selalu berkembang setiap waktu.

Dua sikap di atas tentu tidak bisa diterima begitu saja. Menolak gadget dengan segala manfaatnya, atas nama otonomi manusia bukanlah sikap yang arif karena nyatanya gadget memang membawa banyak manfaat bagi manusia. Adanya gadget membuat dunia semakin sesuai dengan kebutuhan manusia. Namun demikian, larut dalam hingar bingar dunia gadget dan menghabiskan setiap detik dalam hidup hanya untuk bermain dengannya, juga bukan sikap yang bijaksana. Ketika manusia sadar bahwa gadget yang diciptakannya ternyata membawa dampak melebihi yang diharapkan; dan kemudian mengubahnya sesuai dengan yang diharapkan, pun juga belum tentu membawa keadaan menjadi lebih baik. Lalu, apa solusi dari persoalan ini?

Teknologi dengan berbagai isu yang muncul karena relasinya dengan manusia, adalah salah satu isu utama di era kontemporer saat ini. Setiap saat manusia menjalani hidupnya dengan teknologi yang salah satunya mewujud dalam bentuk gadget. Dahulu, manusia lebih memilih tidak membawa handphone daripada tidak membawa dompet. Kini, telah banyak yang berubah. Lebih baik dompet ketinggalan daripada iPhone yang ketinggalan. Awalnya, manusia menggunakan gadget hanya sebagai sarana atau media untuk berkomunikasi dengan manusia yang lain. Kini, manusia lebih sering berkomunikasi dengan gadget-nya. Mengutip pernyataan Marshall McLuhan, gadget tidak lagi menjadi media, karena media itu kini sudah menjadi message itu sendiri. Berpijak pada perubahan tersebut, oleh karenanya manusia perlu merekonstruksi relasinya dengan teknologi, dalam hal ini gadget. Kajian filsafat manusia tentu perlu ikut berperan dalam proses ini.

Bagi penulis, ada dua hal yang harus diperhatikan untuk 
'memperbaiki' relasi manusia dan teknologi bernama gadget. Pertama, pernyataan kunci dari Jacques Ellul perlu diperhatikan, yaitu bahwa teknologi kini perlu diperlakukan layaknya 'organisme'. Selama ini, manusia mungkin menempatkan gadget hanya sebagai perangkat atau sebagai objek yang selalu menjadi sasaran dari perbuatan manusia. Relasi ini perlu dikonstruksi ulang dengan relasi subjek-subjek, bukan lagi subjek-objek. Peran kajian filsafat manusia dalam hal ini bisa dirumuskan dalam beberapa hal. Pertama, filsafat manusia membantu manusia memahami apa yang sebenarnya sedang terjadi. Filsafat manusia membantu manusia mempertanyakan apa yang sebenarnya terjadi dalam relasi manusia dan gadget. Ribuan tahun lalu, Socrates mengatakan bahwa hidup yang tidak direfleksikan adalah hidup yang layak dihidupi. Kini, ketika dunia manusia dilingkupi oleh teknologi, refleksi manusia perlu diarahkan kepada teknologi. Dari refleksi semacam ini akan muncul kesadaran akan hal-hal yang tersembunyi di balik selubung teknologi; determinismenya, otonominya, aditifnya, dan sebagainya. Ketika manusia memiliki kesadaran bahwa "ada sesuatu yang negatif" dari teknologi yang digunakan, maka sesungguhnya itu sudah selangkah lebih maju dibandingkan terlarut begitu saja dalam teknologi. Setelah kesadaran itu muncul, manusia perlu menjaga jarak dengan teknologi yang ia gunakan. Ia bisa memilih, terlarut, tenggelam, berselancar di atasnya, atau memilih tidak menyentuhnya. Dengan begitu, otonomi manusia tetap ada, paling tidak otonomi untuk menentukan sikapnya terhadap teknologi yang akan dipakainya.

Kedua, perlu juga memperhatikan pandangan Adelbert Snidjers yang mengemukakan bahwa teknologi lahir karena dan untuk manusia, bukan sebaliknya. Kesadaran inilah yang perlu terus dikembangkan dalam setiap relasi manusia dan teknologi. Manusia memang makhluk yang paradoksal. Dalam diri manusia, terdapat aspek material dan spiritual sekaligus. Namun demikian, lewat teknologi, manusia justru bisa memaknai kembali relasi antara yang material dan spiritual tersebut. Ratusan, bahkan ribuan tahun yang lalu, materi selalu dilawankan dengan roh sehingga memunculkan pandangan dualistik. Menurut Snidjers, perkembangan teknologi berpeluang mengubah 
pandangan manusia atas dirinya sebagai roh dan materi sekaligus. Lewat teknologi yang sebenarnya berdimensi material, manusia menyadari bahwa roh dan materi bukanlah dua kenyataan yang bertentangan, melainkan saling membutuhkan satu sama lain. Materi bukanlah lawan, tetapi kawan manusia. Manusia memiliki idealisme tentang dunianya, yang kemudian dimaterialisasi-kan dalam bentuk teknologi. Ketika teknologi tidak dapat 'bekerja' sebagaimana yang diharapkan oleh rohani manusia, menurut Snidjers, bukan materinya (teknologinya) yang salah melainkan manusianya yang belum menemukan cara bagaimana idenya (rohaninya) dapat terwujud dalam materi.

Mencermati dua solusi yang disampaikan di atas, dapat disimpulkan bahwa kata kunci untuk tetap menjaga otonomi manusia atas teknologi adalah pada kesadaran manusia. Pertama, manusia harus sadar bahwa teknologi perlu diperlakukan layaknya subjek; dan kedua, manusia harus sadar bahwa teknologi ada untuk manusia, sebagai sarana atau media untuk me-materialkan ide-ide dan gagasan manusia. Semuanya mengarah pada satu tujuan: demi membuat dunia manusia sesuai dengan kebutuhan manusia. Dengan berpegang pada dua hal tersebut, maka otonomi manusia atas teknologi akan tetap ada.

\section{DAFTAR PUSTAKA}

Anonim. 2017. Before the Apple Watch: A history of smartwatches, in pictures, http://www.zdnet.com/pictures/before-the-iwatch-a-history-ofsmartwatches-in-pictures/ diakses 12 Oktober 2016, pukul 10.43 WIB

Bakker, J.W.M.. 1984. Filsafat Kebudayaan. Yogyakarta: Kanisius.

Don Reisinger. 2016. Apple Watch Is Dominating the Global Smartwatch Market, http://fortune.com/2016/09/21/apple-watch-marketshare/?iid=leftrail diakses 12 Oktober 2016 pukul 10.53 WIB

Gadget, http://dictionary.cambridge.org/dictionary/english/gadget pada tanggal 12 Oktober 2016, pukul 09.25 WIB

Koentjaraningrat. 2004. Kebudayaan, Mentalitas, dan Pembangunan. Jakarta: Gramedia Pustaka Utama. 
Lim, Francis. 2008. Filsafat Teknologi, Don Ihde tentang Dunia, Manusia, dan Alat. Yogyakarta: Kanisius.

Muhaimin. 2016. Pria Amerika Ini Nikah dengan iPhone di Las Vegas, http://international.sindonews.com/read/1121173/46/pria-amerika-ininikah-dengan-iphone-di-las-vegas-1467354145, diakses pada tanggal 29 November 2016, pukul 09.31 WIB

Scharff, Robert C., and Dusek, Val, (Ed.). 2003, Philosophy of Technology, The Technological Condition, An Anthology. Oxford: Blackwell Publishing.

Sihotang, Kasdin. 2009. Filsafat Manusia, Upaya Membangkitkan Humanisme. Yogyakarta:Kanisius.

Snidjers, A..2004. Manusia, Sebuah Paradoks dan Seruan. Yogyakarta: Kanisius. 